\title{
Święty Augustyn
}

\section{LIST 87 [DO EMERYTA]}

(Epistula 87, CPL 262)*

\section{WSTĘP}

1. Adresat listu. Adresatem listu napisanego przez św. Augustyna między 405 a 411 r. był Emeryt ${ }^{1}$, biskup stolicy prowincji cesarstwa, nazywanej Mauretania Caesariensis. Była to najdalej wysunięta na zachód afrykańska prowincja, tak daleka, że - jak pisze sam Augustyn - jej mieszkańcy nie do końca uważali ją za część Afryki². Sama Mauretania odległa była od najważniejszych ośrodków miejskich, takich jak Kartagina o ponad $400 \mathrm{~km}$.

Emeryt był jednym z najważniejszych biskupów donatystycznych w czasach św. Augustyna. Badacze donatyzmu zwracają uwagę na jego negatywne cechy charakteru, William Hugh Clifford Frend opisuje go jako ,,a long-winded, pedantic and exasperating speaker"3, natomiast Paul Monceaux - „capricieux et pretentieux”, ,tour a tour muet et bavard" ". Zawdzięcza to m.in. temu w jaki sposób sformułował on wyrok na wzmiankowanym często u Augustyna synodzie w Bagai. Odbył się on w kwietniu 394 r. i zdecydował o wyrzuceniu ze wspólnoty donatystów grupy obrońców biskupa Maksymiana. Augustyn cytuje wypowiedzi Emeryta, które rzeczywiście są dosyć ostre nawet jak na standardy antycznej inwektywy 5 .

* Praca powstała w ramach realizacji projektu badawczego finansowanego ze środków Narodowego Centrum Nauki (2015/17/D/HS2/01238).

${ }^{1}$ Najlepszym źródłem informacji o Emerycie, wraz z bogatymi odwołaniami do źródeł, pozostaje hasło Emeritus 2, w: Prosopographie de l'Afrique chrétienne: (303-533). Prosopographie chrétienne du Bas-Empire, éd. A. Mandouze et al., Paris 1982, 340-349.

${ }^{2}$ Por. Augustinus, Epistula 93, 24, ed. A. Goldbacher, CSEL 34/2, Vienna 1898, 469: „Mauretania tamen Caesariensis occidentali quam meridianae parti uicinior, quando nec Africam se uult dici”.

${ }^{3}$ W.H.C. Frend, The Donatist Movement, A movement of protest in Roman North Africa, Oxford 1971, 281.

${ }^{4} \mathrm{P}$. Monceaux, Histoire littéraire de l'Afrique chrétienne depuis les origines jusqu'à l'invasion arabe, t. 6: Littérature Donatiste au temps de Saint Augustin, Paris 1922, 144.

${ }^{5}$ Augustinus, Contra epistulam Parmeniani 2, 7, ed. M. Petschenig, CSEL 51, Vindobonae 1908, 51: „licet enim uiperei seminis noxios partus uenenati uteri alueus diu texerit et concepti sceleris uda coagula in aspidum membra tardo se calore uaporauerint, tamen conceptum uirus euanescenti umbraculo celari non potuit. nam etsi sero publicum facinus et parricidium suum feta sce- 
Jako człowiek wykształcony retorycznie - co wielokrotnie podkreśla Augustyn Emeryt był jednym z częściej zabierających głos na konferencji w Kartaginie w 411 roku' ${ }^{6}$. Augustyn poświęcał mu najwyraźniej dużo uwagi, skoro zasłużył on sobie na odrębne podsumowanie tego wydarzenia zatytułowane Ad Emeritum post Collationem ${ }^{7}$. Jeszcze raz słyszymy o Emerycie w Żywocie Augustyna pióra Possydiusza z Kalamy. W 418 r. stary, ponad sześćdziesięcioletni i schorowany Augustyn udał się w długą drogę do Mauretanii, gdzie odbył z Emerytem bardzo osobliwą debatę. Emeryt bowiem wypowiedział w niej tylko trzy krótkie zdania, stwierdzając, że nie jest zainteresowany czynnym udziałem w tej dyskusji, ponieważ akta Konferencji w Kartaginie potwierdzają kto w sporze ma rację, a po wygłoszeniu tych uwag milczał, chociaż Augustyn formalnie wyzywał go na pojedynek w formie doktrynalnego agonu ${ }^{8}$. Czy celem tej podróży była właśnie dyskusja z Emerytem, nie wiemy. Possydiusz wspomina o tym, że Augustyn nie działał w pojedynkę, a bezpośrednią motywację do odwiedzenia Emeryta znalazł on w listach, które nadeszły z Rzymu od papieża Zozyma9.

2. Układ treści. W omawianym liście Augustyn porusza po raz kolejny podstawowe kwestie dzielące Kościół afrykański na początku V wieku. W pierwszym paragrafie Augustyn thumaczy powody napisania go, a następnie przechodzi do zagadnienia możliwości bycia splamionym przez grzechy innego członka wspólnoty, zwłaszcza przez nieujawnione grzechy. Podkreśla też fakt, że donatyści nie są znani Kościołom spoza Afryki (paragrafy 1-3). W czwartym i piątym paragrafie Augustyn zarzuca donatystom niekonsekwencję, polegającą na tym, że tolerują złoczyńców w swojej wspólnocie, a za przykładowy czarny charakter służy tu Optat, biskup Thamugadi, stronnik Gildona. Zarzut niekonsekwentnego rygoryzmu i hipokryzji ponowiony jest w paragrafie szóstym, gdzie Augustyn nawiązuje do niekonsekwencji donatystów w traktowaniu swojej wewnętrznej schizmy, mianowicie maksymianistów. Augustyn broni następnie stanowiska dopuszczającego ingerencję władz świeckich w sprawy kościelne (paragrafy 7-8), by zakończyć podkreśleniem jedności Kościoła i możliwości poprawy błędów przez samych donatystów (paragrafy 9-10).

3. Argumentacja. Należy przyznać, że właściwie nie wiemy, dlaczego Augustyn pisze do Emeryta. Reguły gatunku epistolarnego i zasady dobrego wychowania wymagały, by we wstępie nawiązać do okoliczności, które skłoniły nadawcę do napisania

lerum uota pepererunt". Augustyn cytuje ten fragment akt synodu w Bagai także w: Contra litteras Petiliani 1, 21; Ad Cresconium 4, 2; Gesta cum Emerito 10.

${ }^{6} \mathrm{O}$ ważnej roli jako actor na tym sądzie donatystów pisze też Possydiusz (Vita Augustini 14, 4), potwierdzają ją także Gesta Conlationis Carthaginensis, a ich analizie A. Mandouze (Emeritus 2, s. 341-347) poświęca aż siedem stron z dziesięciu przeznaczonych na całą sylwetkę Emeryta.

${ }^{7}$ Omawiał to niezachowane dzieło w Retractationes II 46 (ed. A. Mutzenbecher, CCL 57, Turnhout 1974, 127-128). Zaczynało się od słów: „si uel nunc, frater Emerite”.

${ }^{8}$ Por. Augustinus, Gesta cum Emerito 3, ed. M. Petschenig, CSEL 53, Vindobonae 1910, 183 184; tenże, Retractationes II 51, CCL 57, 129-130).

${ }^{9}$ Por. Possidius, Vita sancti Augustini 72-73. Zob. B.D. Shaw, Sacred violence: African Christians and sectarian hatred in the age of Augustine, Cambridge - New York 2011, 11-13. 
listu. Zazwyczaj w swoich listach polemicznych Augustyn odnosi się do konkretnych, ważnych okoliczności, które zmusiły go do napisania listu, często będącego bezpośrednią reakcją na wspomniane we wstępie wydarzenie ${ }^{10}$. Tutaj biskup Hippony pozornie czyni zadość temu wymogowi, jednak powody napisania listu, które podaje, mogły jedynie rozgniewać Emeryta. Ironia, a właściwie zwykła kpina, ukryta pod polorem wzniosłego stylu nawet się tu nie czai: Emeryt przedstawiony jest tu bowiem jako wykształcony głupiec. Należy więc z całą pewnością odrzucić sugestię Jennifer Ebbeler, że w korespondencji antydonatystycznej Augustyn eksperymentuje z nową formułą korespondencji jako medium służącego poprawie doktrynalnych błędów epistolarnego partnera ${ }^{11}$. Augustyn był wytrawnym retorem, wieloletnim nauczycielem retoryki i doskonale wiedział, że wstęp służy przede wszystkim pozyskaniu przychylności odbiorcy. Musiał więc zdawać sobie sprawę, że wstęp jego listu nie zachęcił Emeryta do spokojnego wysłuchania jego dalszej części. Moim zdaniem, list ten, podobnie jak i inne listy kierowane formalnie do konkretnych biskupów donatystycznych (Epistulae 49, 51 i 93), jest skierowany przede wszystkim do szerokiej publiczności po obu stronach sporu jako do sędziów w sporze ${ }^{12}$.

Uwagę w tym liście zwraca przede wszystkim formalna rama, którą Augustyn tworzy przez ciagłe odwoływanie się do kontekstu sądowego. Występuje tu wiele słów, które miały swoje techniczne, prawnicze znaczenie, na którym Augustyn przez cały czas gra i co starałem się oddać w przypisach: causa, inquisitio, declarare, intendere, quaerere. Po drugie, Augustyn explicite przedstawia siebie i Emeryta jako dwie strony sporu sądowego, w którym sędzią jest Bóg (paragraf 10). Emeryt pełni tutaj rolę reprezentanta całej oskarżonej grupy, która tak naprawdę jest sądzona (paragraf 4). Po trzecie Augustyn, jak prawnik w sądzie cały czas dąży do przedstawienia status finitionis, co - jak wiemy z antycznej teorii retorycznej - było ważne przede wszystkim w sprawach kryminalnych.

\section{WYDANIA TEKSTU}

J. P. Migne: Paris 1841, PL 33, 296-302.

A. Goldbacher: Vienna 1898, CSEL 34/2, 397-406.

Kl.D. Daur: Turnhout 2005, CCL 31A, 132-138.

\section{PRZEKŁADY NOWOŻYTNE}

Angielskie:

W. Parsons S.N.D., Washington 2008, Letters, Volume 2 (83-130), The Fathers of the Church 18, 12-22.

R. Teske, Hyde Park, 2001, Letters 1-99, The Works of Saint Augustine a Translation for the 21st Century II/1, 344-350.

\footnotetext{
${ }^{10}$ Por. np. Augustinus, Epistula 33; 49; 51; 108.

${ }^{11}$ Por. J. Ebbeler, Disciplining Christians, Oxford 2012, 151-189.

${ }^{12}$ J. Ebbeler (tamże, s. 182-183) zwraca na to zagadnienie niedostateczną uwagę.
} 
Francuskie:

M. Poujoulat, Bar-Le-Duc 1864, Lettres de saint Augustin, tome 2, dostęp on-line: http://abbaye-saint-benoit.ch/saints/augustin/lettres/s002/1087.htm [24.05.2017].

$\mathrm{Niemieckie:}$

A. Hoffmann, München 1917, Ausgewählte Briefe (Erster Teil), BKV 29, dostęp on-line: http://www.unifr.ch/bkv/awerk.htm [24.05.2017].

Włoskie:

L. Carozzi, Roma 1969, Lettere 71-123, dostęp on-line: http://www.augustinus.it/ italiano/lettere/lettera_087_testo.htm [24.05.2017].

\section{BIBLIOGRAFIA}

P. Monceaux, Histoire littéraire de l'Afrique chrétienne depuis les origines jusqu'à l'invasion arabe, t. 6: Littérature Donatiste au temps de Saint Augustin, Paris 1922; W.H.C. Frend, The Donatist Movement, A movement of protest in Roman North Africa, Oxford 1971, passim; Emeritus 2, w: Prosopographie de l'Afrique chrétienne: (303-533). Prosopographie chrétienne du Bas-Empire, éd. A. Mandouze et al., Paris 1982, 340-349; Cz. Mazur, Listy św. Augustyna - bibliografia, w: Św. Augustyn, Listy, tłum. W. Eborowicz, Pelplin 1991, 421-449; J. Divjak, Epistulae, AL II 893-1057; B.D. Shaw, Sacred violence: African Christians and sectarian hatred in the age of Augustine, Cambridge - New York 2011, 3-16, 85-89 i 706-709; J. Ebbeler, Augustine, the Donatists, and Litterae Pacificae, w: Shifting cultural frontiers in late antiquity, ed. D. Brakke - D. Mauskopf Deliyannis - E.J. Watts, Farnham 2012, 115-128.

\section{PRZEKŁAD ${ }^{* *}$}

Wytęsknionemu i ukochanemu bratu, biskupowi Emerytowi

1. Kiedy słyszę, że ktoś obdarzony dobrym intelektem ${ }^{13}$ i wykształcony w sztukach wyzwolonych - chociaż to nie od nich zależy zbawienie duszy - w kwestii najprostszej z prostych sądzi coś zgoła innego niż tego wymaga prawda, bardzo się dziwię ${ }^{14}$. A im bardziej się dziwię, tym bardziej płonę pragnieniem poznania człowieka i pomówienia $\mathrm{z}$ nim ${ }^{15}$. Jeśli nie byłoby to

${ }^{* *}$ Przekładu dokonano z łacińskiego tekstu, opracowanego przez A. Goldbachera: Augustinus, Epistulae, CSEL 34/2, Vienna 1898, 397-406

${ }^{13} \mathrm{~W}$ oryginale: bono ingenio praeditus.

${ }^{14}$ Augustyn formułuje wstęp przy zachowaniu podręcznikowych zasad pisania pochwały - laus, wskazując na podstawową cnotę charakteryzującą adresata listu i pochwały, mianowicie cnotę mądrości i zaznaczając, że jest ona zarówno wrodzona, jak i wyćwiczona. Tym większy jest kontrast między pierwszą pochwalną częścią zdania, a jego konkluzją i dalszym ciągiem listu, w którym Augustyn koncentruje się na wykazaniu oczywistych niekonsekwencji w postępowaniu donatystów oraz niespójności między głoszonymi przez nich poglądami i postępowaniem.

${ }^{15} \mathrm{~W}$ tej chiastycznej sekwencji tkwi oczywista ironia. Augustyn, podobnie jak w innym antydonatystycznym liście (Epistula 93, 4), stosuje fałszywe pochlebstwo. 
możliwe, pragnę przynajmniej w listach, które dolatują na najdalsze odległości, dotknąć jego umysłu i poczuć jego odwzajemniony dotyk. Jak słyszę, ty jesteś takim właśnie mężem, ale, nad czym boleję, pozostajesz oderwany i oddzielony od Kościoła powszechnego, który, jak to zapowiedział Duch Święty, rozlewa się na cały świat (por. Ps 2,8). Nie wiem, jaki jest tego powód. Pewne jest natomiast, że dla wielkiej części świata rzymskiego, że nie wspomnę już o ludach barbarzyńskich - a [sam] Apostoł nazwał się także ich dłużnikiem (por. Rz 1, 14) - z którymi tworzymy wspólnotę chrześcijańskiej wiary, sekta Donata $^{16}$ jest nieznana i w ogóle nic o nich [tj. donatystach] nie wie: ani o tym, kiedy ani też $\mathrm{z}$ jakich powodów odstępstwo to zostało zapoczątkowane ${ }^{17}$. I jeśli nie uznasz zgodnie $\mathrm{z}$ logiką ${ }^{18}$ tych wszystkich chrześcijan za niewinnych tych zbrodni, które zarzucacie mieszkańcom Afryki, będziesz zmuszony nazwać was wszystkich splamionymi, jako dotkniętych winą od złych czynów wszystkich [ludzi], ponieważ niegodziwcy wśród was pozostają, żeby to łagodnie określić, nieodkryci.

Nie jest bowiem tak, że nie wyrzucacie nikogo ze swojej wspólnoty, albo wówczas dopiero wyrzucacie, kiedy zrobił już to, za co zostaje wyrzucony. Czyż nie karzecie tak kogoś, kto przez jakiś czas pozostawał w ukryciu, a dopiero potem został ujawniony i skazany? Pytam więc, czy zhańbił was w tym czasie, kiedy pozostawał w ukryciu, odpowiesz: w żadnym wypadku. W żadnym czasie nie splamiłby nas, nawet gdyby zawsze jego zbrodnia pozostawała w ukryciu. Albowiem liczne występki osób już zmarłych wychodzą na jaw, co nie czyni grzesznikami chrześcijan, którzy pozostawali w komunii z nimi za ich życia. Dlaczego więc wy odcięliście się za jednym lekkomyślnym i świętokradczym zamachem od komunii z niezliczonymi Kościołami na Wschodzie, które nigdy nie wiedziały i do tej pory nie wiedzą, co - jak wy oznajmiacie lub wymyślacie ${ }^{19}$ - zdarzyło się w Afryce.

2. Inna bowiem sprawa ${ }^{20}$ dotyczy tego, czy mówicie prawdę o tych wydarzeniach. Wykazujemy przecież na podstawie o wiele bardziej godnych zaufania dokumentów, że są one fałszywie [przedstawiane] ${ }^{21}$ i to samo, co wyście podawali w wątpliwość, po przedstawieniu dowodów głosimy przeciw wam ${ }^{22}$.

${ }^{16}$ Gra słów: pars Donati nie jest znana magnae parti Romani orbis.

${ }^{17} \mathrm{~W}$ oryginale: dissensio.

${ }^{18}$ Tak thumaczę utique.

${ }^{19}$ Zarzut kłamstwa, jak często w listach przeciw donatystom pojawia się tu w delikatnej formie. Augustyn zazwyczaj używa go raczej w kontekście kpiny niż inwektywy, por. Augustinus, Epistula 53,$1 ; 105,2 ; 141,1 ; 141,8 ; 185,6$.

${ }^{20} \mathrm{~W}$ oryginale: Alia enim quaestio est. Quaestio ma techniczne znaczenie: postępowania sądowego, śledztwa, procesu oraz potoczne: pytania, wątpliwości, zagadnienia. Augustyn gra na obu znaczeniach, kontekst sądowy nie powinien nam umknąć w czasie lektury tego listu.

${ }^{21}$ Znów odwołanie do procedury sądowej - convincere na podstawie dokumentów bardziej prawdopodobnych.

${ }^{22}$ In uestris declaramus - declarare też ma sądowe znaczenie ogłaszać wyrok, uznawać za winnego. 
Lecz to jest, jak powiedziałem, inna sprawa, którą należy podjąć i rozwiązać wówczas, gdy będzie to konieczne ${ }^{23}$. Teraz niech twój czujny umys $\mathfrak{1}^{24}$ zechce zwrócić uwagę na fakt, że nikt nie może zostać splamiony przez nieznane zbrodnie nieznanych osób. Dlatego jest rzeczą oczywista, że oddzieliliście się świętokradczą schizmą od komunii z całym światem, który zupełnie nie zna i nigdy znał nie będzie tych czy to prawdziwych czy fałszywych zbrodni, o które wy oskarżacie ${ }^{25}$ mieszkańców Afryki. Jednakże nie należy milczeć także i o tym, że w Kościele nawet rozpoznani złoczyńcy nie zawadzają dobrym, jeśli brak jest władzy by zabronić im komunii, albo jeśli powstrzymuje od tego wzgląd na utrzymanie pokoju ${ }^{26}$. Po cóż bowiem są ci, którzy u proroka Ezechiela (por. Ez 9, 4-9) zasłużyli na to, by uczynić znak [na ich czole] tuż przed zniszczeniem niegodziwców, i by wyszli nienaruszeni, chociaż wygubiono tamtych, jeśli nie po to, by w ten sposób stali się jak najwyraźniej widoczni ci, którzy wzdychają i biadają nad grzechami i nieprawościami ludu Bożego, popełnianymi pośród nich? Kto zaś wzdycha i biada nad tym, o czym nie wie? $\mathrm{Z}$ tego samego względu także apostoł Paweł znosi fałszywych braci, nie mówi bowiem o nieznanych: bo wszyscy szukają własnego pożytku, a nie - Jezusa Chrystusa (por. Flp 2, 21), a jednak wyjawia, że byli oni z nim. A do jakiego sortu należą ci, którzy woleli raczej złożyć bożkom ofiarę z kadzidła lub wydać boskie kodeksy niż umrzeć, jeśli nie do tych, którzy szukają własnego pożytku, a nie - Jezusa Chrystusa.

3. Pominę liczne świadectwa z Pisma Świętego, aby nie sprawiać, że list stanie się dłuższy niż jest to konieczne, oraz aby pozwolić twojej erudycji, byś sam rozważył liczne [inne świadectwa] ${ }^{27}$. Proszę cię jednak, abyś przyjrzał się temu, co [powinno] wystarczyć. Jeśli tak liczni niegodziwcy w jednym ludzie Bożym, nie uczynili tych, którzy ich przestrzegali (por. Neh 9, 26), takimi jakimi sami byli, jeśli owa wielka liczba fałszywych braci (por. Ga 2, 4; 2Kor 11, 26) znajdujących się $z$ Pawłem $w$ jednej wspólnocie kościelnej nie sprawiła, że szukał on własnego pożytku, a nie - Jezusa Chrystusa (por. Flp 2, 21), jest rzeczą oczywistą, że fakt, iż istnieje jakiś zły człowiek z którym podchodzimy

${ }^{23}$ To praeteritio zgodnie z podręcznikowym użyciem służy potęgowaniu ironii, por. H. Lausberg, Retoryka literacka, tłum. A. Gorzkowski, Bydgoszcz 2002, 476-477 (§ 884).

${ }^{24}$ Vigilantia mentis tuae - czujność twojego umysłu to znów oczywista ironia, ponieważ po raz kolejny, tak jak na wstępie będzie expressis verbis podkreślał oczywistość dyskutowanych problemów i słuszności własnego stanowiska.

${ }^{25}$ Intendere - to w znaczeniu technicznym: występować ze skargą w sądzie.

${ }^{26}$ Ratio conseruandae pacis. O przedstawianiu siebie jako czyniącego pokój w listach przeciw donatystom pisała Jennifer Ebbeler, Augustine, the Donatists, and Litterae Pacificae, w: Shifting cultural frontiers in late antiquity, ed. D. Brakke - D. Mauskopf Deliyannis - E.J. Watts, Farnham 2012, 115-128; tenże, Disciplining Christians, Oxford 2012, 115-128.

${ }^{27}$ Po raz kolejny praeteritio jest ironiczne, tutaj poprzez połączenie z fałszywym komplementem. Ma ono tu dwojakie uzasadnienie: po pierwsze jest odwołaniem do klasycznej wartości brevitas oraz komplementem (znów ironicznym) - jeśli tyle jest świadectw dowodzących absurdalności stanowiska donatystów, człowiek oczytany powinien je znać. 
do ołtarza Chrystusa, (nawet jeśli [jego występny charakter] nie jest nam nieznany), nie wpływa na człowieka, jeśli tylko nie pochwalamy go i odłączamy go od naszego dobrego sumienia czując niechęć do [złych uczynków]. Jest więc rzeczą oczywista, że nie można współdziałać ze złodziejem inaczej niż kraść wraz z nim lub też uznawać jego kradzież za miłą sercu. Mówimy to po to, by oddalić nie mające końca i zbędne kwestie dotyczące uczynków ludzi, które w niczym nie wpływają na naszą argumentację.

4. Lecz i wy, jeślibyście nie podzielali tego poglądu, wszyscy bylibyście tacy, jaki był w waszej wspólnocie Optat ${ }^{28}$, którego [charakter] nie był wam nieznany, co oby nie było możliwe w przypadku obyczajów Emeryta i innych spośród was, którzy, nie wątpię ${ }^{29}$, są bardzo dalecy od jego występków. Nie zarzucamy wam bowiem nic innego niż zbrodnię schizmy, z której uczyniliście herezję przez zgubny upór. A jakim boskim wyrokiem karany jest taki występek - przeczytaj to, co, nie wątpię, już czytałeś (por. Lb 16, 1-35) ${ }^{30}$. Znajdziesz tam Datana i Abirama, których otworzywszy paszczę pożarła ziemia i wszystkich pozostałych, którzy się z nimi zgadzali, pochłoniętych przez ogień, który wybuchł pośród nich. Pan Bóg napiętnował tę zbrodnię błyskawiczną karą jako przykład tego, czego należy się wystrzegać, aby wskazać jaki ostateczny werdykt zastrzega sobie w sprawie tych, którym do czasu, z najwyższą cierpliwością pobłaża. Nie ganimy bowiem waszego stanowiska z owego czasu, gdy Optat - jak dało się słyszeć - miotał się w szale, kiedy to jęk całej Afryki służył za jego oskarżyciela i wyście jęczeli wraz z innymi. Zakładając oczywiście, że jesteś taki, jak głosi fama - a Bóg wie, że wierzę w to i życzę sobie tego. Nie ganimy was zatem, jeśli w owym czasie, nie chcieliście go ekskomunikować, aby nie pociągnął ze sobą wielu wraz z nim ekskomunikowanych i nie podzielił waszej wspólnoty obłędem schizmy ${ }^{31}$. Lecz to jest właśnie to, co dowodzi waszej winy ${ }^{32}$ na sądzie Bożym, bracie Emerycie, ponieważ, chociaż widzieliście, że jest tak wielkim złem dzielić stronnictwo Donata ${ }^{33}$, iż uznaliście, że należy raczej pozostawać z Optatem w komunii, niż dopuścić do rozłamu, trwaliście w owym złu, którego dopuścili się wasi przodkowie dzieląc Kościół Chrystusa.

5. Tutaj być może, z powodu wąskiego wyboru kontrargumentów, spróbujesz bronić Optata ${ }^{34}$. Nie próbuj, bracie, nie próbuj, proszę. Nie przystoi

\footnotetext{
${ }^{28}$ Donatystyczny biskup Thamugadi w Numidii, który popierał Gildona, przywódcę rebelii.

${ }^{29}$ Znów ironiczna pochwała Emeryta i innych donatystów, która może być zrozumiana zarówno jako komplement jak i oskarżenie.

${ }^{30}$ Znów zwraca uwagę użycie prawniczego słownictwa i osadzenie dyskusji w kontekście sporu sądowego, gdzie oskarżonymi o zbrodnię są donatyści, a sędzią jest Bóg.

${ }^{31}$ Furor schismatis - to określenie nie odnosi się wprost do donatystów, ale do ewentualnej schizmy wewnątrz ich grupy. Rozumiejąc jednak metonimicznie Augustyn określa tak też schizmatycką grupę donatystów.

${ }^{32}$ Arguere ma techniczne znaczenie: oskarżać, wykazywać, dowodzić.

${ }^{33} \mathrm{~W}$ oryginale lepiej widoczna jest kpina, gdyż stronnictwo to po łacinie pars - część, a więc coś, co już jest podzielone.

${ }^{34}$ Tę formę argumentu nazywamy wyprzedzeniem zarzutów.
} 
ci - być może przystałoby komuś innemu, jeśli w ogóle coś przystoi złym ludziom - ale z całą pewnością Emerytowi nie przystoi bronić Optata. Lecz być może oskarżać również nie? Zgoda, niech i tak będzie ${ }^{35}$. Użyj pośredniego tonu $^{36}$ i powiedz: „Każdy niesie własny ciężar” $(\mathrm{Ga} 6,5)$. Kim jesteś ty, co się odważasz sądzić cudzego sługę?" (Rz 14,4). Jeśli więc zgodnie ze świadectwem całej Afryki, a właściwie wszystkich ziem, gdziekolwiek zła sława Gildona budziła emocje, znany był zarazem i Optat, nie odważyliście się nigdy zwołać sądu w jego sprawie, aby bez namysłu nie wyrokować o tym, co nieznane, czy my rzeczywiście możemy i powinniśmy bez namysłu wydawać wyrok w sprawie tych, którzy żyli przed nami, na podstawie jedynie waszego świadectwa, jakby jeszcze zbyt mało było, że wy formułujecie oskarżenie o nieznanych sprawach, jeśli i my nie wydamy wyroku o tym, co nieznane ${ }^{37}$. Albowiem nawet jeśli Optat znalazł się w niebezpieczeństwie z powodu fałszywej zawiści, to nie jego bronisz, ale siebie, kiedy mówisz: „Nie wiem, jaki on był", o ile więc bardziej wschodni świat jest nieświadomy tego, jacy byli mieszkańcy Afryki, których ty uznajesz za winnych, chociaż są mniej znani. Od tych [wschodnich] Kościołów, których imiona masz w księgach i czytasz je na głos, oddzieliłeś się jednak niegodziwym odstępstwem ${ }^{38}$. Jeśli tego waszego najsłynniejszego i najgorzej zniesławionego biskupa Thamugadi nie znał jego własny kolega, w tym samym czasie będący biskupem, nie powiem Cezarei ale nawet Sitifis, w jaki sposób afrykańskich traditores, kimkolwiek by nie byli, mógł poznać Kościół Koryntian, Efezjan, Kolosan, mieszkańców Filippi, Tesaloniczan, Antiocheńczyków, mieszkańców Pontu, Galacji, Kapadocji i Kościoły z innych części świata, wzniesione przez apostołów w Chrystusie, albo też w jaki sposób zasłużyły one na potępienie od was, skoro nie mogli ich [tj. traditores] $\mathrm{znac}^{39}$. A jednak nie pozostajecie $\mathrm{z}$ nimi w komunii, mówicie, że nie są chrześcijanami i próbujecie ich przechrzcić. Co mam powiedzieć? Na co się skarżyć? ${ }^{40}$ Albo o czym krzyczeć? O ile rozmawiam z człowiekiem roztropnym ${ }^{41}$, oburzenie to kłuje swym żądłem również mnie, bo na pewno widzisz, co mógłbym powiedzieć, gdybym tylko chciał ${ }^{42}$.

6. A może wasi przodkowie zwołali synod i potępili cały świat chrześcijański z wyjątkiem siebie? Czy już do tego stopnia zanikła zdolność sądzenia,

\footnotetext{
${ }^{35}$ Augustyn używa tu stylizacji na dialog - bezpośrednich zwrotów do adresata i jego prawdopodobnych wypowiedzi w formie sermocinatio.

${ }^{36}$ Media uox - pośredni ton, styl pomiędzy wysokim, a niskim. Być może jest w tym jakaś uszczypliwa aluzja do wybuchowego stylu samego Emeryta.

${ }^{37}$ Rozpoczyna się cały łańcuszek argumentów zbudowanych w formule a minori/e ad maius.

${ }^{38}$ Nefaria dissensio - to typowe określenie w pismach antyheretyckich.

${ }^{39}$ Augustyn dokonuje tutaj reductio ad absurdum rozumowania donatystów, wskazując brak ciagłości w ich myśleniu.

${ }^{40}$ Por. Cicero, In Verrem IV 44, 97.

${ }^{41} \mathrm{Tu}$ po raz kolejny Augustyn posługuje się ironicznym komplementem.

${ }^{42}$ Augustyn, jak w całej kontrowersji z donatystami, tak i tu znów przedstawia siebie w roli łagodnego oskarżyciela i sugeruje, że znaleźć można o wiele więcej zarzutów niż on tu zawarł.
} 
że synod maksymianistów, którzy odszczepili się od waszej szczepki, nie ma żadnej mocy przeciw wam, ponieważ w porównaniu z wami są oni bardzo nieliczni, a wasz synod ma moc przeciw narodom Chrystusa $i$ jego posiadaniu po krańce ziemi (por. Ps 2, 8)? Dziwię się, że ma w swoim ciele krew ten, kto nie rumieni się na te słowa ${ }^{43}$. Proszę odpisz na nie. Od wielu osób, którym nie mogłem nie uwierzyć, słyszałem, że odpiszesz, jeśli do ciebie napiszę. Już nawet wcześniej wysłałem jeden list - nie wiem, czy go dostałeś, czy odpowiedziałeś na niego, a ja, być może, nie otrzymałem odpowiedzi. Teraz jednak prosze, nie ociaggaj $\operatorname{się}^{44} \mathrm{z}$ odpowiedzią, co o tym sądzisz. Lecz nie próbuj zabierać się za inne kwestie. Stąd bowiem bierze swój początek prowadzone w najlepszej zgodzie z prawem dochodzenie ${ }^{45}$ : dlaczego doszło do schizmy.

7. Albowiem także władze świeckie, kiedy ścigają schizmatyków, bronią się zgodnie z regułą, którą ustanowił Apostoł: „Kto więc przeciwstawia się władzy - przeciwstawia się porządkowi Bożemu. Ci zaś, którzy się przeciwstawili, ściągną na siebie wyrok potępienia. Albowiem rządzący nie są postrachem dla uczynku dobrego, ale dla złego. A chcesz nie bać się władzy? Czyń dobrze, a otrzymasz od niej pochwałę. Jest ona bowiem dla ciebie narzędziem Boga, [prowadzącym] ku dobremu. Jeżeli jednak czynisz źle, lękaj się, bo nie na próżno nosi miecz. Jest bowiem narzędziem Boga do wymierzenia sprawiedliwej kary temu, który czyni źle" (Rz 13, 2-4). Cała zatem sprawa sprowadza się do tego, czy schizma nie jest niczym złym, albo inaczej: czy nie doprowadziliście do schizmy i stawiacie opór władzom, bo czyniliście dobro, a nie zło, za co ściagnęliście na siebie wyrok potępienia. Dlatego też Pan powiedział najbardziej przewidująco: „Błogosławieni, którzy cierpią prześladowanie dla sprawiedliwości, albowiem do nich należy królestwo niebieskie” (Mt 5, 10). Pragnę więc dowiedzieć się od ciebie, zgodnie z tym, co powiedziałem wyżej, czy sprawiedliwościa jest to, czym się kierowaliście w waszym odstępstwie, w którym wciąż trwacie. A jeśli niesprawiedliwością jest potępić cały chrześcijański świat bez przesłuchania - ponieważ nie dosłyszał tego, co wy usłyszeliście, albo też nie dowiedziono przed nim tego, w co wy bez namysłu uwierzyliście, albo o co oskarżyliście bez żadnego pewnego dokumentu - bo wam oczywiście wolno chcieć przechrzcić tyle Kościołów samego

${ }^{43}$ Ta uwaga skierowana jest tyleż do adresata, ile do postronnych odbiorców. W ten sposób Augustyn sugeruje czytelnikom listu reakcję emocjonalną.

${ }^{44}$ Augustyn rozwiązuje zatem retorycznie przed chwilą postawioną kwestię dotyczącą braku odpowiedzi na jego wcześniejszy list. W kontekście antycznych tradycji epistolarnych odpowiadanie na listy było po prostu konieczną grzecznością. Przedstawianie swojego adresata jako nieczyniącego zadość temu wymogowi było po prostu kolejnym argumentem przeciw niemu w polemicznej korespondencji.

${ }^{45}$ Augustyn znów formułuje debatę w kategoriach prawnych. W teorii retorycznej jednym z ważniejszych zadań w procesie sądowym było ustalenie status finitionis dotyczącego tego, jaka była istota zbrodni, jak należy ją zakwalifikować. By to ustalić wymagane było przeprowadzenie śledztwa, dochodzenie - inquisitio, które jak mówi tu Augustyn jest ordintatissima - czyli dosłownie najlepiej uporządkowane, najlepiej poparte zwyczajem prawnym (ordo). 
Pana, założonych w czasie gdy był on jeszcze w ciele, dzięki przepowiadaniu i trudowi Jego apostołów; wolno wam nie znać waszych złych/niecnych kolegów-biskupów afrykańskich równocześnie z wami żyjących, razem z wami sprawujących sakramenty, a nawet znać i tolerować, byle stronnictwo Donata nie uległo podziałowi; a tym, którzy zajmują najdalsze krańce ziemi nie wolno nie wiedzieć, co też wy o mieszkańcach Afryki wiecie, albo co wierzycie, [że wiecie] albo co usłyszeliście, albo co zmyśliliśsie - jak wielką przewrotnością jest pielęgnować swoją niesprawiedliwość i oskarżać władzę o surowość?

8. „Lecz jednak nawet niecnych chrześcijan nie należy prześladować”. Dobrze, niech nie będzie wolno. Lecz czy jest rzeczą słuszną czynić z tego zarzut władzom do tego właśnie celu wyznaczonym przez prawo? Czyż wymażemy Apostoła? Czy wasze kodeksy nie zawierają tych [wersów], które przed chwilą przypomniałem. „Lecz wy - powiesz - nie powinniście pozostawać w komunii z takimi ludźmi”. Cóż zatem? Czy wy nie pozostawaliście w komunii z Flawianem, niegdyś wikariuszem ${ }^{46}$, człowiekiem z waszego stronnictwa, ponieważ posłuszny prawom zabijał złoczyńców, których wytropił? „Lecz wy - powiesz - podburzacie cesarzy rzymskich przeciwko nam". A nawet wy sami [podburzacie ich] przeciw sobie, którzy ważyliście się odciąc się schizmą i macie odwagę chrzcić ponownie Kościół, którego oni są członkami, co zostało o wiele wcześniej przepowiedziane - bowiem o Chrystusie powiedziano: „I oddadzą mu pokłon wszyscy królowie ziemi” (Ps 72, 11). Nasi [stronnicy] natomiast domagają się od prawem wyznaczonych władz ochrony przeciw bezprawnym, prywatnym aktom przemocy waszych ludzi, nad którymi i wy bolejecie i płaczecie tam, gdzie się takich czynów nie dopuszczacie. Domagają się jej nie po to, by was dzięki niej prześladować, ale by bronić siebie, tak samo jak apostoł Paweł, zanim jeszcze Cesarstwo Rzymskie stało się chrześcijańskie, starał się, by przydzielono mu ochronę zbrojnych przeciw Żydom spiskującym, by go zabić. Lecz w jakikolwiek sposób dowiadują się o waszej niegodziwej schizmie owi władcy, wydają oni w waszej sprawie takie postanowienia, jakie chcą, zgodnie z własną troską i władzą. Bo nie na próżno noszą miecz. Są bowiem narzędziami Boga do wymierzenia sprawiedliwej kary

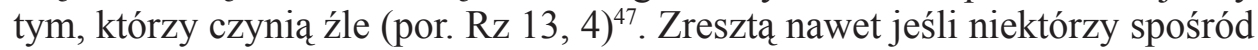
naszych ludzi czynią to nie z chrześcijańskim umiarkowaniem - nie podoba nam się to; jednakże z ich względu nie opuszczamy Kościoła katolickiego jeśli przed czasem ostatecznego oczyszczenia ziaren z plew nie potrafimy go z nich oczyścić (por. Mt 3,12) - tak jak i wy nie opuściliście stronnictwa Donata ze względu na Optata, gdy nie mieliście odwagi go odrzucić.

9. „Lecz jednak dlaczego chcecie, żebyśmy się do was przyłączyli, jeśli jesteśmy przestępcami?" Ponieważ wciąż jeszcze żyjecie i możecie się poprawić, jeśli byście zechcieli. Kiedy bowiem połączycie się z nami, to jest

\footnotetext{
${ }^{46}$ Po reformach Dioklecjana był to podporządkowany prefektowi praetorio zarządzający diecezją.

${ }^{47}$ Por. paragraf 7, który rozpoczynał tę linię argumentacji; zawierał on w części wstępnej ten sam cytat w bliższej Pismu Świętemu formie, z czasownikami i zaimkami w liczbie pojedynczej.
} 
z Kościołem Bożym, dziedzictwem Chrystusa, w którego posiadaniu są krańce ziemi (por. Ps 2,8 ), poprawicie się sami ${ }^{48}$, aby żyć w korzeniu. Tak bowiem mówi Apostoł o wyłamanych gałęziach: „Bo Bóg ma moc wszczepić je ponownie" (Rz 11, 23). Wasza zmiana zachodzi zatem w tym, w czym dokonaliście odstępstwa, chociaż sakramenty, które macie, są święte, ponieważ są te same u wszystkich. Z tego względu pragniemy, byście dokonali zmiany w waszej przewrotności, to jest aby odcięta przez was samych szczepka na nowo się zakorzeniła. Albowiem akceptujemy sakramenty, których nie zmieniliście, tak jak je macie, by przypadkiem, kiedy to chcemy naprawić waszą ułomność, nie uczynić świętokradczej krzywdy misteriom Chrystusa, które nie stały się ułomne przez waszą ułomność. Ani bowiem Saul nie uczynił ułomnym namaszczenia, które otrzymał - temu to namaszczeniu wielką cześć okazał pobożny sługa Pana, król Dawid (por. 2Sm 1, 1-16). Z tego też względu pragnąc przywrócić was korzeniowi, nie chrzcimy was ponownie, a jednak akceptujemy formę odszczepieńczego sakramentu, jeśli nie uległa zmianie; chociaż jest ona zdrowa, nie przynosi owocu skoro brak jej korzenia. Inna sprawa dotyczy prześladowań, których, jak mówicie, doświadczacie przy tak wielkiej łagodności i delikatności naszych ludzi, chociaż zaiste prywatnie wasi ludzie dokonują cięższych wykroczeń przeciw prawu, inna zaś chrztu - nie pytamy bowiem, gdzie ma miejsce, ale gdzie ma moc ${ }^{49}$. Gdziekolwiek bowiem by nie był, jest to ten sam chrzest, co nie znaczy, że ten kto, go przyjmuje, gdziekolwiek by nie był, jest taki sam. A zatem okazujemy niechęć wobec niegodziwości prywatnych osób [pozostających] w schizmie, lecz chrzest Chrystusa czcimy wszędzie, ponieważ jeśliby dezerterzy porwali ze sobą sztandary cesarskie, gdy zostaną oni ukarani wyrokiem skazującym lub poprawią się dzięki łaskawości, sztandary odzyskuje się nietknięte, jeśli pozostały nietknięte. I jeśli w tej materii potrzebne jest jeszcze jakieś bardziej szczegółowe dochodzenie, jest to, jak już powiedziałem, inna sprawa. W takich kwestiach powinno się bowiem stosować zasady, które stosuje Kościół Boży.

10. Śledztwo dotyczy zatem tego, czy to wasz, czy nasz Kościół jest Boży. $\mathrm{Z}$ tego względu należy prześwietlić na początku to, dlaczego dokonaliście schizmy. Jeśli nie odpiszesz, sądzę, że mam u Boga [na sądzie] prostą sprawę, ponieważ wysłałem pisma dążące do zaprowadzenia pokoju, mężowi, który, pominąwszy kwestię schizmy, ma sławę dobrego i wykształconego w sztukach wyzwolonych. Przyjrzyj się, co odpowiesz Jemu, którego cierpliwość teraz należy chwalić, ale którego wyroku na końcu należy się obawiać. Jeśli jednak odpisałbyś z taką troska, z jaką widzisz, że napisałem do ciebie, miłosierdzie Boga dopomoże, aby kiedyś, dzięki umiłowaniu pokoju i rozumowaniu w prawdzie, zniknął błąd, który nas dzieli. Pamiętaj, że nie mówiłem o rogacjanach, którzy, jak się mówi, nazywają was firmianami, tak jak wy

${ }^{48}$ Rym bierze się tu stąd, że próbowałem oddać łacińską figurę homoioteleuton: nobis coniugimini... vos corrigimini.

${ }^{49} \mathrm{~W}$ oryginale gra słów ubi sit... ubi prosit. 
nazywacie nas makarianami, ani też o waszym biskupie Rusykki, który zawarł z Firmusem pakt o bezpieczeństwie swoich ludzi, aby bramy zostały dla niego otwarte, a katolicy wydani na zgubę, ani o niezliczonych innych rzeczach. Przestań więc wyolbrzymiać ludzkie czyny, o których słyszałeś lub które znasz, za pomoca tych wyświechtanych argumentów ${ }^{50}$. Widzisz bowiem, jakie wasze [sprawki] przemilczałem, aby całe postępowanie toczyło się wokół źródła schizmy, gdzie znajduje się sedno sprawy. Niech Pan Bóg natchnie cię pokojowymi myślami, wytęskniony i ukochany bracie. Amen.

Z języka łacińskiego przełożył, wstępem i przypisami opatrzył Rafał Toczko***

${ }^{50} \mathrm{~W}$ oryginale: locis communibus. Locus communis to oczywiście literacki topos, którego definicję Augustyn najpewniej znał z Cycerona. Th.D. Frazel (The rhetoric of Cicero's „In Verrem”, Hypomnemata 179, Göttingen 2009, 57-59), zwraca uwagę na podobieństwo do definicji locus communis w Progymnasmatach Theona (106, 5-6) i Cycerona (De inventione 2, 48).

*** Dr Rafał Toczko - adiunkt w Katedrze Filologii Klasycznej na Wydziale Filologicznym Uniwersytetu Mikołaja Kopernika w Toruniu; e-mail: raftocz@umk.pl. 